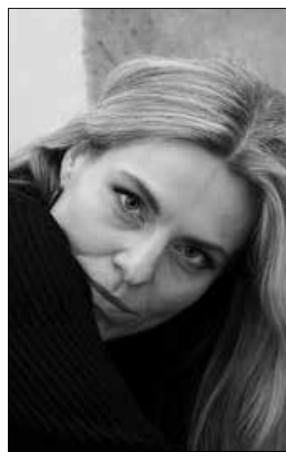

https://doi.org/10.24101/logos.2017.20

Gauta 20161020

Pabaiga. Pradžia Logos 89

\title{
DEIMA KATINAITÉ
}

Vilniaus dailès akademija, Lietuva

Vilnius Academy of Arts, Lithuania

\section{KANDINSKIS BAUHAUSE - ORIENTALISTISTINIAI IR NEKLASIKINIAI JO SPALVOS TEORIJOS ASPEKTAI}

\author{
Kandinsky in the Bauhaus - Oriental \\ and Non-Classical Aspects of His Color Theory
}

\begin{abstract}
SUMMARY
This article reveals different aspects of the color theory of Wasilly Kandinsky, which was set out in his treatise Über das Geistige in der Kunst: Insbesondere in der Malerei published in 1911. This theory - an ode to spiritual and abstract art - was inspired by non-classical philosophy, W. Worringer and the aesthetic attitudes of Eastern art. It had a strong impact on the Bauhaus design school even before the author of this theory was invited to teach at the Bauhaus in year 1922. The oriental ideas of Kandinsky significantly differed from the ideas of the Bauhaus manifesto, published by Walter Gropius in 1919. His theory encompasses the theme of color along with many other topical issues of the art. One could view this theory as an ontology-based study of the color phenomenon. The problems of art in Kandinsky's theory have been discussed beyond narrowly-understood aesthetic discourse, along with the philosophical questions of life, death, spirit and matter.
\end{abstract}

\section{SANTRAUKA}

Straipsnyje kompleksiškai analizuojama modernistinio meno korifejjaus, vieno abstrakcionizmo pradininku Vasilijaus Kandinskio spalvos teorija, išdèstyta jo $1911 \mathrm{~m}$. išleistame programiniame veikale Über das Geistige in der Kunst: Insbesondere in der Malerei. Ši neklasikinès filosofijos, W. Worringerio ir Rytu estetikos įkvèpta Kandinskio odè abstrakčiam ir dvasingam menui turëjo stiprų poveikị Bauhauso dizaino mokyklai, jos spalvos teorijai dar iki tol, kol jos autorius $1922 \mathrm{~m}$. buvo pakviestas dèstyti. Orientalistinès estetikos įkvèpto Kandinskio idejjos smarkiai skyrèsi nuo $1919 \mathrm{~m}$. Walterio Gropiuso paskelbto Bauhauso manifesto idèjų. Jo estetinė teorija aprépia ne tik spalvą, bet ir daugybę kitų aktualių dailès ir meninès 
kūrybos procesų psichologijos problemų. Tai tarsi ontologizuota spalvos fenomeno meno filosofija, kai meno problematika svarstoma neapsiribojant siaurai suprastu estetikos diskursu, bet įtraukiami filosofiniai gyvenimo, mirties, dvasios ir materijos klausimai.

\section{SINESTEZIJA IR INNERE NOTWENDIGKEIT}

Sinestezijos fenomeną ir vidinès bütinybès sąvoką iš esmès kylančią iš šios Kandinskio gebos, galime laikyti raktu i dailininko spalvos teoriją. Sinestezija (gr. synaisthesis - suvokimas, jautimas vienu metu) yra igimtas neurologinis reiškinys, kai susilieja du (ar daugiau) pojūčiai: klausos, regos, skonio, uoslès, lytëjimo. Sinestetinè geba, būdinga visiems žmonėms kūdikystëje, vèliau išnyksta arba tiek susilpnëja, kad imama tapatinti su vaizduote. Daliai žmoniu sinestetiniai gebejimai išlieka. Sinesteziją dažniausiai atpažistame jai reiškiantis (pasirodant ivvairiomis meno formomis) estetikos srityje. Rytų kraštų kultūroje sinestetinis principas atrodo organiškas ir natūralus, japonư, kinų menui būdinga, kad dailininkas dažniausiai yra ir poetas, muzikas, etc. Orientalistinè estetika, apibendrintai tariant, yra sintetinès prigimties: Rytų kraštų filosofijoje nesant ontologinès skirties tarp kūno ir proto/ dvasios (priešingai nei racionalistinèje, binarine logika grịstoje Vakaru tradicijoje), ivvairiu, skirtingos sensorinès kilmès, meninès raiškos formų sąsajos yra tipiškas ir natūralus dalykas.

Tuo tarpu Vakaru kultūroje sinestezijos biologinis pradas ilgą laiką sietas su patologija, psichiatrijoje aiškintas kaip tam tikra haliucinacijos forma, o sinestetinè geba ir XXI a. neretai artikuliuojama kaip tam tikras sinestetų menininkų neapsisprendimas ar svyravimas tarp skir- tingų meno sričių. Puikiu lietuvišku pavyzdžiu galètu būti sinesteto M. K. Čiurlionio vienpusiškas, visiškai nepagrịstas dažniausiai jo tik kaip dailininko iškèlimas, tačiau, pasak taiklios A. Andrijausko pastabos, „priešingai paplitusiems požiūriams, jis niekuomet nemetė muzikos, o kūrẻ lygiagrečiai muzikos, tapybos, literatūros srityse. Jam, kaip daugeliui universalistų, būdinga ir filosofinè refleksija ${ }^{\prime 18}$. Sinestezijos dovaną turèjo daugelis garsių kūrëjų: J. W. Goethe, I. Stravinsky, Ch. Baudelaire'as, R. Wagneris, A. Skriabinas, Nikolajus Rimskis-Korsakovas, V. Nabokovas, V. Woolf, Ch. J. Joyce'as, W. Faulkneris, Carlo Carra, O. Messiaenas, A. Schönbergas, A. Rimbaud, etc.

Salomëja Jastrumskytè, skyrusi sinestezijos fenomenui daktaro disertacija, rašo: „Šiuolaikinès sinestezijos apibrèžimai bešališkai rodo galimus visu pojūčiu susipynimus apskritai, bet ju neišskiria ir nežymi. Todèl vienų ar kitu sinestezijos faktu išskyrimas ir naudojimas jos sąvokos plètotei veikiausiai atskleidžia, jog sinstezijos sklaidoje esama ne tik statistiniu, demografinių itaku, bet savotiškos tradicijos, kai kuriais atvejais ryškiai apsibrěžiančios savo ribas. ${ }^{\prime 19}$ Tokia tradicija galime laikyti dèl Vakaru okuliarcentrizmo įtakos susiklosčiusią būdingiausią tapybos ir muzikos sinestetinès jungties artikuliacija, del kurios dominavimo kitos galimos, orientalistinèse kultūrose lygiagrečios garsui ir vaizdui sensorinès 
paralelès atsiduria meno pasaulio periferijoje. Europinio okuliarcentrizmo globalumą iliustruoja tarsi savaiminis jo „akivaizdumas". Viktorija Žilinskaitè, tyrinèdama okuliarcentrizmo metodologiją iš socialinių mokslų perspektyvos, teigia, kad „vizualinès kultūros vieta Vakarų kultūroje paprastai nèra sociologiškai pagrindžiama ar aptariama. Vaizdo svarba konstatuojama kaip savaime suprantama..." ${ }^{20}$ Okuliarcentrizmo įsitvirtinimo europinejje humanistikoje priežasčių reikètų ieškoti humanitarinių mokslų raidoje, visu pirma ištakose - antikinès ir krikščioniškosios kultūros tradicijoje.

Vakarietiškoms kalboms būdingas žodžių "matyti“ ir "suprasti“ sinonimiškumas, taip pat gajus atskirų žodžių, sąvokų vienos kurios reikšmės istorinis ìsitvirtinimas, o Rytų kraštų lingvistikoje neretai žongliruojama kitokių, subtilesnių, pustoninių kokybiu terminija, ju neredukuojant dèl aiškumo ir nesibaiminant tokio termino atveriamų interpretaciju ìvairovès. Pavyzdžiu galètų būti kinų kalbos sąvoka wei, neretai vartojama literatūros kritikoje ir reiškianti ,,skoniّ“ arba „prieskonį“21 (jei bus rašoma skirtingais hieroglifais, gali turèti dar daug kitų reikšmių). Kadangi ši sąvoka yra kitos sensorinès prigimties nei Vakarų kultūroje, hierarchiškai aukščiausiai esantys regos ir klausos pojūčiai, tikètina, kad „prieskonio“ terminas vakarietiškame kontekste (pavyzdžiui, literatūroje ar meno kritikoje) atrodys perdèm nekonkretus, sunkiai apčiuopiamas ir bus suprastas kaip kalbos figūra, reiškianti koki nors ispūdį. Lygiai taip pat vakariečiui sunku suvokti dzen estetikos kategorijų daugiaspalviškumą ir rasti lingvistinius atitikmenis verčiant ju pavadinimus i europines kalbas.

Veikiausiai dèl vakarietiškos pojūčių hierarchijos Kandinskio spalviniai teoriniai ir praktiniai tyrinejimai mums labiausiai asocijuojasi su vaizdo (spalvos) ir garso (muzikos) paralele, atlikta daugiausia šios krypties tyrimų. Kandinskio filosofines nuostatas formavo muzikos svarbą iškeliančios neklasikinès estetikos atstovu A. Schopenhauerio, F. Nietzsche's meno filosofijos idejos, kurios susipynè su romantizmo ir simbolizmo krypčių menininkų idealais, svarbia idèjine ištaka tapo naujos modernizmo estetikos, kurios išskirtinès svarbos figūromis tapo Kandinskis ir Klee, principai. Juc estetinių idealų, susijusių su radikaliais neoromantizmo virsmais i modernizmo estetiką, isigalèjimui būdingas teorijos ir praktikos suartèjimas, jausmų pasaulio sureikšminimas, posūkis psichologizmo ir subjektyvizmo link bei stiprëjanti Rytu Azijos estetikos principu ir dailès sklaida.

Būtent dèl šių galingu estetiniu ir meniniu sajūdžiu, susijusiu su subjektyvizmo tendenciju stiprèjimu Vakaru meninejje samoneje, ittakos muzika modernizmo estetikoje igavo aukščiausiojo meno statusa. Kadangi Kandinskiui buvo svetimas vakarietiškas mimesis principas, simbolizmas ir muzikalumas jo kūryboje skleidžiasi ne ženkliškai, kaip formalus perkèlimas, bet turinio prasme, kai vaizdu / spalva perteikiamos ne tam tikros muzikinès formos struktūros, o siekiama fundamentalios sintezès, giluminio, skirtingos sensorikos reprezentantų susipynimo, kurio reika- 
lauja vidine būtinybé. Nepaisant indèlio i muzikos ir tapybos jungti, kuri nèra nauja (muzika užėmė reikšmingą vietą Blaue Reiter dailininkų ieškojimuose), svarbiausiu spalvotyriniu sinestetiniu Kandinskio atradimu reikètų laikyti spalvų sąsajas su kitomis sensorinemis patirtimis - kvapais, lytejjimu etc.

Anot dailininko, spalvos suvokëją veikia dvejopai: pirmiausia patiriame trumpalaiki fiziologini spalvos poveiki, kuris nepaliečia sielos ir pranyksta tik nusukus akis, tačiau šis pirminis, paviršutiniškas susidūrimas gali būti postūmis pasirodyti, iškilti daugeliui su spalva susijusiu pojūčių. Kur kas svarbesnis yra psichologinis spalvų poveikis, kuri turètume patirti susidūrę su bet kokiu nauju fenomenu, panašiai kaip vaikas patiria pasauli: mato šviesa, o vėliau atranda kitas šviesos savybes, formuojančias šviesos žini$j a$, - ji gali deginti, šildyti etc. Ši procesą Kandinskis vadina nuviliančiu pasaulio atkerejimu $^{22}$, kai tapdamas iprastu, jis praranda pirminio pojūčio intensyvumą. Jo knygos Über das Geistige in der Kunst skyriuje apie psichologini spalvų poveiki galime ižvelgti aliuziją i kūdikiškas sinestetines patirtis, kurios plečiasi, jei šis gebejjimas išlieka (kaip autoriaus atveju). Kandinskis rašo, jog žmogui ugdantis, patirtys, sukeltos skirtingų objektų ar būviu, iggauna vidinę reikšmę ir galiausiai pasiekia dvasinę harmoniją. Taip pat veikia spalva, kurios net pirminis trumpalaikis poveikis gali atverti kokybiškai skirtingas jausenas, priklausomai nuo patiriančiojo sielos jautrumo: ,jautresnei sielai spalvu poveikis yra gilesnis ir intensyviai sukrečiantis ${ }^{\text {“23. }}$.
Pažymėtina, kad Kandinskis nevartoja termino sinestezija, tačiau jo svarstymas apie spalvų psichologinio poveikio prigimtị leidžia spèti ši gebejjimą turint mintyje: "Ar psichologinis poveikis yra tiesioginis, kaip rodo paskutinès kelios eilutès (jose rašo apie spalvos sukeliamas dvasines vibracijas. - Aut. past.), ar tai yra asociacijų rezultatas, turbūt yra atviras klausimas. “24 Tos pačios spalvos poveikis gali kelti priešingas asocioacijas, kurias ne visada imanoma suklasifikuoti. Pasak Kandinskio, yra daugybè spalvos poveikio niuansų, kurie tam nepasiduoda; jis aprašo sinestezijos atveji, kai pacientas skundèsi gydytojui negalis valgyti padažo, nes mato mèlyną spalvą.

Anot Kandinskio, tai rodo, jog esti ypatingo sielos jautrumo žmonių, kai kelias i sielą tiesioginis, ji tokia pagauli ispūdžiams, kad bet koks pojūtis pirma užgauna sielą ir tada persiduoda kitiems organams, aprašytuoju atveju - akims. Taip yra ne tik dèl skonio. Daugelis spalvų gali būti apibūdintos kaip šiurkščios ar lipnios, kitos tokios švelnios ir lygios, kad norisi braukti per jas (tamsus ultramarinas, chromo oksido žalia, rožinè). Taip yra ir dèl skirčių i šiltas ir šaltas spalvas: kai kurios atrodo minkštos (rose madder), kitos kietos (žalias kobaltas, mèlynai žalias oksidas), kad net šviežias dažas tūbelèje atrodo sausas. Taip pat Kandinskis mini "kvepiančias spalvas“, pasak jo, toks posakis dažnai sutinkamas $^{25}$. Dailininkas rašo privalantis pripažinti, kad spalvų poveikis esąs neištirtas, bet spalva daranti didžiulę itaką kūnui kaip fiziniam organizmui. Kandinskis mini chromaterapiją ir jos ivvai- 
rialypi poveiki kūnui bei psichologinę asociacijų teoriją. Viena vertus, jis tarsi bando suteikti sinestetinems patirtims objektyvumo statusa, sakydamas, kad sunku įsivaizduoti, jog kas nors bandytu išreikšti ryškiai geltoną spalvą bosinèmis natomis ar tamsų ežerą perteikti diskan$\mathrm{tu}^{26}$, ir pasitelkia Skriabino, A. SacharinUnkowskos ir kitus tyrimus kaip pavyzdžius. Kita vertus, pripažista spalvų poveikio ivvairialypiškuma, sakydamas, kad jei asociacijų teoriją išmėgintume eksperimentuodami su gyvūnais ar augalais, ši patektų i aklavietę.

Taigi iš šių svarstymų matome Kandinskio suformuluotos spalvų teorijos tikruosius užmojus ir universalumą: ji apima ne tik tapybos ir muzikos santyki, pačias ivvairiausias sensorines patirtis, šakojasi skirtingomis kryptimis, netikètais ekskursais, kai svarbi supanti aplinka, gamta, i kurią dažnai nurodoma. Kandinskio kalba metaforiška ir ekspresyvi, o apibendrinimai, kuriais užbaigia skyrius, dažnai labiau primena poetizuotus, emocionalius teiginius nei mokslines išvadas. Jo metodas panašus ị Itteno, kai formos požiūriu nuosekli dèstymo struktūra sukuria racionalumo îspūdì, tačiau turini sudaro laisvi filosofiniai pamąstymai, tolimi mokslinio darbo schemai „problema - argumentas - i̇rodymas“. Gražiu pavyzdžiu gali būti dažnai cituojama Kandinskio frazè, kuria jis užbaigia knygos Apie dvasinguma mene skyrių Psichologinis spalvos poveikis (The Psychological working of color): „Spalva yra klaviatūra, akys yra plaktukai, siela yra fortepijonas su daug stygu. Menininkas yra ranka, kuri groja, paliesdama tą ar kitą klaviša, kad sukeltų vibracijas sieloje." 27 Ši garsi citata yra ne tik meistriška metafora, čia galime ižvelgti aliuziją i nyčiškosios kuriančiosios dvasinès galios, Rytų kraštų filosofijai būdingą panteistinès vienovès ar tapatumo su aplinka principa, kai menininkas veikia maksimaliai i̇siklausydamas ị aplinka, kol sutampa su meno kūriniu.

Rytų filosofijos ištakas galime atsekti ir jo sąvokos innere Notwendigkeit genezèje. Viena vertus, Kandinskio vidine būtinybe atrodo nuosekliai išsikristalizavusi siekiant reflektuoti sunkiai suvokiamą (ir labai ribotai tuo metu ištirtą) sinestezijos fenomeną, su juo tiesiogiai susidūrus. Visų pirma ši frazè atrodo paranki paaiškinti spontaniškai kylančias asociacijas, kurių prigimtis iracionali: „Todèl akivaizdu, kad spalvų harmonija turi remtis tik atliepiančia vibracija žmogiškoje sieloje; tai vienas pagrindinių vidinés bütinybès principų. ${ }^{28}$ Antra, vidinés būtinybés principas yra natūralus atgarsis tuometinių filosofinių judejjimų, vadinamosios Zeitgeist, organiškas atspindys: romantizmo posūkio i̇ vidujybę, genijaus kulto, emocionalumo, subjektyvumo ir individualumo, maišto prieš XVIII a. materializmą ir racionalizmą, buvusių taisyklių nepaisymo, jausmų ir vaizduotès svarbos išryškinimo, su simbolizmu iškylančio meno galios sureikšminimo, intuicijos, paslapties, vidujybès priešinimas viskam, kas išoriška. Kandinskiui artimas Schopenhaueris, kuris nukelia intelektą nuo pjedestalo ir paverčia instinktyvių poelgiu pagalbiniu izrankiu. Vadinasi, jis Kandinskiui plačiai atveria duris kūniškumo ir pasąmonès pažinimui, apnuogina slèpiningą meta- 
fizini pasaulio pagrinda, jo esmę ir kartu tarsi „priartina“ reiškinių gelminès esmès pažinimą tiesiogine patirtimi. Menas čia, kaip ir Jenos romantiku panestetizme, yra sureikšminamas, jis gali net stabdyti laiką yra vienas iš triju pasipriešinimo savaiminei valiai mechanizmų. Schopenhauerio individuacijos principą (principium individuationis), kaip leidžianti prisiliesti prie esmés, taip pat, nedaug nusižengdami tiesai, galime laikyti Kandinskio vidinés bütinybès provaizdžiu. Vidine būtinybe yra ta versmè, iš kurios kyla meniniai impulsai, galintys keisti žmoniją, rodyti kelią dvasingumo link. Vadinasi, ši sąvoka turi ir etini aspektą.

Taip pat salygiškai, aptardami galimas principo innere Notwendigkeit ištakas, galime ji palyginti su nyčiškojo įkvépimo sąvoka, kuri išskleista Dioniso ditirambuose (Dionysos Dithiramben ${ }^{29}$ ). Tai yra tam tikra ekspresyvumo galia, taip sakantis principas, duodantis postūmius formos ir turinio kismui. Anot M. T. H. Sadlerio, Kandinskio sąvoka innere Notwendigkeit pirmiausia reiškia menininko jaučiamą dvasinès ekspresijos impulsą ir kartais autoriaus vartojama išreikšti pačią ekspresiją $q^{30}$ (the actual expression itself). Kandinskis iš Nietzsche's perima genijaus kulta, jo aprašytoje vertybinès piramidès schemoje (The movement of the triangle ${ }^{31}$ ) rašoma apie amžininkų nesuprastus lyderius, kurie laikomi ekscentriškais, laikotarpius, kai menas domisi išorybe, nejuda i prieki (yra ",retrogresiškas“), nes nèra tinkamo lyderio.

Nepaisant Kandinskio svarstymu apie tuometinio meno dekadansa, jo filosofija yra teigianti (taip kaip ir jo įkvèpejo Nietzsche's), tikima, kad menas gali išgelbèti pasaulį: laukiama nematomo Mozės, kuris nusileis nuo kalno ir atneš šviežius išminties vèjo gūsius. Pirmiausia jo balsa, negirdimą miniai, išgirs menininkai ir beveik nesamoningai juo seks. Esminio filosofinio prasminio klausimo „kas“ interpretacija Kandinskio pateikta kaip perkèlimas, kai tokiame klausime nebeieškoma senų laikų former time) objektyvybès ${ }^{32}$, bet klausimas pats tampa vidine tiesa, siela, be kurios kūnas (tapatus klausimui „kaip“) niekada nebus sveikas. Šioje interpretacijoje matome po nyčiškosios Dievo mirties atsivèrusios, tapatybės principu grịstos pasaulio griūties refleksiją. Vidinès bütinybès sąvoką galime laikyti tam tikru Kandinskio spalvos teorijos spiritus movens, steigiančiuoju vardikliu, kurio tačiau neturètume mėginti vienareikšmiškai apibrèžti. Tai yra bendrinè nuoroda į vidujybės sfera, atitinkanti Schopenhauerio, Nietzche's ir kitu Kandinskiui artimu autoriu (Baudelaire'o, Maeterlinko etc.) neklasikinès meno filosofijos idejjas, orientalistines šiu ideju ištakas.

Rytų kraštų filosofijos, estetikos įtaka nulèmè daugelį esminių Vakaru estetinès ir meninès sąmonès slinkčių, kurių pagrindinè - nusivylimas racionalistine pasaulèžiūra, binarinio tikrovès suvokimo ir mąstymo logika ir iš to plaukiantis sąmoningas neapibrēžtumas, neužbaigtumas, atvirumas. Kandinskis, darydamas išvadas apie minètas slinktis savo tekste ar teigdamas, neretai apsidraudžia vis iš naujo pabrèždamas bet kokių postulatu sąlygiškumą. Štai svarstydamas apie materialumą ir ne-materialuma, akcentuodamas dvasingumo reikšmę, jis vengia statiško dogmatiškumo, sąvokas 
stengiasi palikti dinamiškas: „Ar gali skirtumai, kuriuos darome tarp materijos ir dvasios, būti tik reliatyvios ko nors modifikacijos? [...] Ar viskas, ko negalime paliesti ranka, yra dvasiška? Diskusija peržengia šios nedidelès knygos ribas; visa, kas čia svarbu, yra tai, kad brèžiamos ribos nebūtų galutinès. " ${ }^{33}$

Taigi matome, kad spalvos teorijos struktūros suvokimui esminius dalykus Kandinskis pasako tarsi tarp kitko, neretai nuorodose, kaip kad šiuo atveju. Ši elegantišką literatūrinès formos „,minkštumą“, kai svarbūs dalykai pateikiami tarsi nepastebimai, Kandinskis veikiausiai igijo nuosekliai studijuodamas orientalistiką. Jis neretai kaltinamas pernelyg klampia kalba, daugiafigūriniais palyginimais, tačiau anapus metaforikos, kuri atspindi dailininko stilių, matome labai skaidrią ir nuoseklią spalvos teorijos sistema, išskirtus pagrindinius "dèmenis", kurie kartu yra ir kartais (sąmoningai) prieštaringos metaforikos raktas. Kandinskis kalba apie atsigręžimą i ,pusiauužmirštus“ laikus ir "pusiau-užmirštus metodus" kitų tautu, i kuriuos žvelgėme iš aukšto ir su gailesčiu ${ }^{34}$. Taip pat mini Indijos kultūrą (vedos yra jam artimo Schopenhauerio etikos pagrindas), Teosofijos draugijos ${ }^{35}$ (Teosophical Society) veiklą ir būdą i dvasines problemas žvelgti iš vidinio žinojimo (inner knowledge) taško, kuris jam atrodo vienintelis įmanomas po to, kai „religija, mokslas ir moralè yra sukrèstos, dvi pastarosios kietos (strong) Nietzsche's rankos “36. Tokiame kontekste jo sąvoka innere Notwendigkeit atrodo organiškas ir tikslingas irankis sinestetiškos spalvos teorijos konstravimui.

\section{IŠVADOS}

Dabar, pereidami prie tyrime išsakytų minčių apibendrinimo, pirmiausia galime teigti, kad Kandinskio spalvos fenomeno daugiasluoksnès, polimorfiškos sistemos teorija nèra vien iš anksčiau gyvavusių estetinių teoriju kylančios idejos, o tiesiog klasikinis teorijos ir praktikos organiškos jungties pavyzdys. Ji išsikristalizavo sinestetinès gebos sąlygotų patirčių dermèje veikiant neklasikinès meno filosofijos ir orientalistinès estetikos idèjoms.

Pamatinę jo estetikoje vartota, psichologizuotą ir tiesiogiai su meninès kūrybos procesu psichologija susijusią vidinès būtinybès sąvoką galime laikyti tam tikru Kandinskio teoriju (tarp ju ir spalvos) spiritus movens, steigiančiuoju vardikliu. Tai yra principas, bendrinè nuoroda i vidujybès sfera, atitinkanti Schopenhauerio, Nietzche's, H. Bergsono, A. Rieglio ir kitų Kandinskiui artimų autorių (Baudelaire'o, Maeterlinko etc.) neklasikinès meno filosofijos idejas.

Todèl vidinès būtinybès principą galime interpretuoti kaip tam tikrą meninès kūrybos proceso organizacini mechanizma Kandinskio pasitelktą kaip metodini iranki siekiant suvaldyti bei sistemiškai teoriškai artikuliuoti efemeriškas ir sunkiai apibrěžiamas sinestetines spalvines patirtis. Viena vertus, tai yra šaltinis ar judintojas, skatinantis meninę intencija, nukreiptą i dvasingumą. Kita vertus, vidinę būtinybę galima suprasti kaip meno, meniškumo arba menininko savasties idealizuotą provaizdi. 


\section{Literatūra ir nuorodos}

18 Antanas Andrijauskas, 623 p.

19 Salomëja Jastrumskytè, Sinestezijos fenomeno konceptualūs virsmai XIX ir XX a. Vakaru meno teorijoje ir praktikoje. Daktaro disertacija. Vilnius, VDA, 2011, p. 63.

20 Viktorija Žilinskaitè, Vaizdo link: okuliarcentrizmas ir jo tyrimo metodologija. Filosofija, Sociologija, t. 21, Nr. 1, p. 3- 10 (cit. p. 4).

${ }^{21}$ Eugene Eoyang, Beyond Visual and Aural Criteria: The importance of Flavor in Chinese Literary Criticizm. Critical Inquiry, Vol. 6, No. 1 (Autumn, 1979), p. 99-100.

22 Wassily Kandinsky, Concerning the spiritual in art, p. 23.

${ }^{23}$ Ten pat, p. 24.

24 Ten pat.

25 Ten pat, p. 25.

${ }^{26}$ Ten pat.

27 Ten pat.

28 Ten pat, p. 26.

29 Dioniso ditirambai yra F. Nietzsche's eilèraščiu ciklas, įdètas priešpaskutinès šio autoriaus knygos Ecce homo. Wie man wird, was man ist. (Ecce homo. Kaip tampama tuo, kas esi) pabaigoje, 1889.

30 Michael T. H. Sadlerio komentaras iš: Wassily Kandinsky, Concerning the spiritual in art, p. 26, nuoroda 4.

31 Wassily Kandinsky, Concerning the spiritual in art, p. 6-9.

32 Ten pat, p. 9.

33 Ten pat, p. 9, nuoroda 3.

34 Ten pat, p. 13.

35 Elena Blavatskaja.

${ }^{36}$ Wassily Kandinsky, Concerning the spiritual in art, p. 14. 